Chiva-Bartoll, O., Gil-Gómez, J., and Zorrilla-Silvestre, L. (2019). Improving the effective personality of pre-service teachers through service-learning: a physical education approach. Revista de Investigación Educativa, 37(2), 327-343. DOI: http://dx.doi.org/10.6018/rie.37.2.303331

\title{
Improving the effective personality of pre-service teachers through service-learning: a physical education approach
}

\author{
Mejora de la personalidad eficaz de maestros/as en formación \\ a través de aprendizaje-servicio: una aproximación desde la \\ educación física
}

\author{
Óscar Chiva-Bartoll, Jesús Gil-Gómez and Lorena Zorrilla-Silvestre \\ *Universitat Jaume I
}

Resumen

El aprendizaje-servicio se ha convertido en una metodología de enseñanza que promueve habilidades sociales y personales relacionadas con la personalidad eficaz. El objetivo de esta investigación fue conocer el efecto de la aplicación de un programa de aprendizaje-servicio sobre la personalidad eficaz de los maestros/as en formación. Se aplicó un enfoque metodológico mixto. Los resultados del análisis cuantitativo revelaron que el programa dio lugar a una mejora significativa de la personalidad eficaz, tanto en la comparación de las mediciones previas y posteriores del grupo experimental, como en la comparación entre las dos mediciones posteriores del cuestionario entre el grupo experimental y el control. El análisis cualitativo complementó estos resultados mostrando que los maestros/as en formación también hicieron alusión a mejoras en dimensiones tales como autorrealización social, autoestima y autoeficacia para la resolución de problemas. Además, su discurso defendió la idoneidad del aprendizaje-servicio para fortalecer e implementar las lecciones teóricas aprendidas durante su formación. En general, estos resultados son consistentes con investigaciones previas que señalan cómo los maestros en formación que participan en aprendizaje-servicio se vuelven más reflexivos y capaces de resolver problemas de interacción con respecto a sus compañeros de clase y otros agentes sociales. En conclusión, la investigación muestra la contribución positiva que ejerce la influencia del aprendizaje-servicio sobre los maestros en formación en términos de contenido de aprendizaje y crecimiento profesional y personal.

Correspondencia: Óscar Chiva-Bartoll, ochiva@uji.es, Av. de Vicent Sos Baynat, s/n 12071 Castellón 
Palabras clave: aprendizaje-servicio, autoeficacia, maestro/a en formación, método pedagógico, educación superior.

\begin{abstract}
Service-learning has become a teaching methodology that promotes social and personal skills related to effective personality. The objective of this research was to know the effect the delivery of a service-learning programme had on the effective personality of primary school pre-service teachers in its application. A mixed methodological approach was applied. The results of the quantitative analysis revealed that the programme resulted in significant effective personality improvement, as much in the comparison of pre-and post-test measurements of the experimental group, as well as the post-test measurements between the experimental and control groups. The qualitative analysis complemented these results by showing that pre-service teachers also made allusion to improvements in dimensions such as social self-realisation, self-esteem and problem solving self-efficacy. In addition, their discourse defended the suitability of service-learning to strengthen and implement the theoretical lessons learned during this training. Overall, these results are consistent with previous research that note how pre-service teachers participating in service-learning become more reflective and able to solve interaction issues concerning both classmates and other social agents. In conclusion, the investigation shows the positive contribution the influence of service-learning makes on pre-service teachers in terms of learning content as well as professional and personal growth.
\end{abstract}

Keywords: service-learning, self-efficacy, pre-service teacher education, educational methods, higher education.

\title{
Introduccion
}

The accelerated changes and complexity of 21st century societies have led to the emergence of different socio-educational discourses and practices (Mayor \& Rodríguez, 2016). Particularly, university education is in need of a renewal centered on creating civic, competent and efficient professionals in the performance of their duties (Álvarez, Martínez, González, Buenestado \& Fernández, 2017; Rodríguez, 2014). Developing effective personality (EP), understood as a construct in which personality features are related in the context of effective professional or academic conduct (Martín del Buey et al., 2000), is posited as a renewal aim. Improving EP implies developing features such as selfesteem, efficacy, motivation, empathy, assertiveness, communication skills and coping with problems, etc. These characteristics can be accomplished in pedagogical ways like collaborative learning and experiential methodologies (Crichton \& Templeton, 2013; He \& Prater, 2014; Hébert \& Hauf, 2015). Specifically, SL is an experiential approach that may address this need (Richards, Eberline, Padaruth \&Templin, 2015). SL is an educational methodology that works on curricular goals and content while providing a significant service to the community (Bringle \& Hatcher, 1996; Deeley, 2015). Moreover, the reflective process inherent in SL teacher students to know themselves better and to interact with their peers, enhancing their empathy and communication skills.

The relationship between SL, PE and pre-service teachers is becoming more consolidated at an international level as the revision by Carson and Raguse (2014) on SL 
in Youth Physical Activity Settings and that of Cervantes and Meaney (2013) about SL in Physical Education Teacher Education demonstrate. Our study is centered on the development of EP in pre-service teachers after a SL programme in PE. It is similar to the investigations carried out by Gil-Gómez, Chiva-Bartoll and Martí-Puig (2015), GilGómez, Moliner-García, Chiva- Bartoll, and García-López (2016), and Wilkinson, Harvey, Bloom, Joober and Grizenko (2013) on similar receptive populations. The reasons that made us provide this service to children with disabilities were: (1) the need to connect the programme to that of the PST curriculum; (2) to promote positive experiences and attitudes towards the inclusion of children with SEN in teacher training (Crawford, 2011; Megan \& MacPhail, 2006; Morley, Balley, Tan \& Cooke, 2005; Tindall, MacDonald, Carroll \& Moody 2015); and (3) the possibility of providing a service to a collective that has a very limited offer of physical activity (Kristén, Patriksson \& Fridlund, 2002).

\section{Theoretical framework}

The background to the EP theoretical construct starts with the research on efficacy by Bandura (1975), approaches on inter and intra-personal intelligence by Gardner (1983), Stenberg's Triarchic Theory (1985), the emotional intelligence of Salovey and Mayer (1990), the social-emotional intelligence of Bar-On (2006) and the personal maturity construct historically drawn together by authors like Heath (1965) and Vaillant and Milofsky (1980). EP encompasses sets of capacities and skills such as assertiveness, self-esteem, capacity for work, self-confidence, emotional stability, the capacity to learn from experience, problem-solving efficacy, future thinking, independence, initiative, goal orientation, etc. (Martín del Buey et al., 2000).

The EP construct consists of four mutually interacting dimensions around the person (Martín del Buey et al., 2008). The first dimension called 'personal strengths' is related to the concept of self and self esteem. The second dimension known as 'personal demands' relates to goal orientation, the power of self-control, task expectations and academic self-realization. The third dimension of the construct is called 'personal challenges'. This dimension is identified with self efficacy at solving problems and is related to coping with difficulty and decision making. The fourth dimension is known as 'personal relationships ' and identifies with the realization of the social self (Martín del Buey et al., 2000).

\section{Service-learning and self-esteem}

Self-esteem is a feature that integrates evaluative individual aspects. This implies positive self-knowledge and self-appreciation, valuing and trusting highly one's own cognitive-motivational and social resources, and closely recognising personal limitations (Gómez, 2012). Authors such as Billig (2002) and Yates and Youniss (1997) emphasize the improvement related to the concept of self and self-esteem in SL. Similarly, Conrad and Hedin (1989), McMahon (1998) and Melchior and Orr (1995) also showed that being protagonists as students in SL programmes improved the concept of self. Similarly, Chambers and Lavery (2012) find tendencies of improved features such as leadership, the ability to self-reflect, self-confidence and self-awareness of one's skills. 
In the same vein, Waters and Anderson-Lain (2014) refer to personal satisfaction, recognition of success in tasks, self-understanding and satisfaction with work that is well done in their studies.

\section{Service Learning and academic self-realization}

Academic self-realisation is a factor related to the 'personal demands' that focuses on the motivation, expectations and performance of academic duties. It refers to the relationship between personal knowledge and the allocation of academic success, highlighting work capacity, intrinsic motivation and achievement in academically related activities (Gómez, 2012). Numerous studies on the effects of SL show a significant increase in motivation (Gallini \& Moely, 2003; Melchior \& Orr, 1995). In relation to academic expectations and responsibilities, Moser and Rogers (2005) stress the increased predisposition towards learning and more coherent understanding of the content worked through on the SL programme students had.

\section{Service Learning and problem solving self-efficacy}

The self-efficacy dimension corresponds to 'personal challenges'. It combines aspects of decision making and coping effectively with challenges and problems. In the area of coping with challenges and problems there are studies that suggest positive SL results in improving traits such as empowerment, personal effectiveness and student resilience (Billig, 2000; Conrad \& Hedin, 1989; McMahon, 1998). Bernadowsky, Perry and Del Greco (2013) also analyzed the effects of SL on pre-service teachers, concluding that the perceived efficacy of the future teachers increased, promoting the ability to know one's abilities and to be effective in one's teaching duties. In regard to planning decisions and analysing situations, Llewellyn and Kiser (2014) suggest improvements after SL participation in developing intellectual growth, critical thinking and problem analysis. In the same vein, Wendler (2012) refers to the increased decision making abilities based on socially relating and interacting with others.

\section{Service Learning and social self-realisation}

The content at the core of social self-realisation is related to 'personal relations'. It involves skills such as communication, assertiveness and empathy. This factor highlights the link between the self-perceived ability to establish and maintain relationships with others and expectations of success in those future social relationships. These features, according to research by Billig (2002) and Yates and Youniss (1997) improved by participation in SL programmes. Regarding empathy, Perry and Katula (2001) ratified changes in awareness and understanding of social issues, with SL participants more sensitive to the social problems of disadvantaged groups. Watson, Crandall, Hueglin \& Eisenman (2002) also reported advances in accepting new views and respect for the disabilities.

Another aspect that links social self-realisation with the effect of SL is that of improving solidarity (Conrad \& Hedin, 1989). This fact, as attested by Melchior and 
Orr (1995), can be attributed to the increase in team working capacity and interaction. In the same vein, the study by Maynes, Hatt and Wideman (2013) refers to improving the perception of SL participants in existing relationships, as well as improving communication skills, intent for action and the beliefs in efficacy for social interaction.

\section{Methods}

\section{Aims of the study}

The objective of this investigation was to know the effect on a group of pre-service teachers participating in a programme delivered to children with disabilities SL had.

\section{Research design and sample}

A combination of methods is always desirable when analyzing educational phenomena related to preservice teachers' conceptions and approaches (Monroy \& GonzálezGeraldo, 2017). Therefore, a mixed research design based on the complementary nature of the quantitative and qualitative analysis was implemented. The quantitative part was chosen by a quasi-experimental design with intervention based on non-equivalent groups and pre- and post-test measurements. Both experimental and control groups were studying the same subject with different methodological approaches, with the application of SL as a differential factor. The sample was formed from a non-probability sampling of two natural groups. In the experimental group 111 pre-service teachers participated (23 male and 88 female, mean age 21.35, SD 2.26) with 110 in the control group (18 male and 92 female, mean age 21.79, SD 5.02).

The qualitative part of the study consisted in turn of two complementary sets of data. On the one hand 15 semi-structured interviews were conducted with various SL participants and, moreover, the learning journal of each participant was analyzed. The interviews were conducted at the end of the SL programme. A sampling process was conducted in two phases. It made a first selection from representative quotes from the participating population; and a second selection was established by reference string or snowball. In the quota phase 10 participants were selected by attending to characteristics such as age, sex and previous experience with disabled children. In the reference string phase, 5 participants were selected because of their active programme participation.

\section{Hypothesis and research question}

The assumptions of the quantitative approach to the study were that SL participants would improve post-test results compared to the control group. In addition, it was expected that the EP scores obtained in the post-test of the experimental group would be an improvement on the pre-test. As for the qualitative part of the study, the research question was: 'What does the personal and academic training of the programme mean for the SL participants? 


\section{Intervention Programme}

The intervention program consisted of applying SL methodology in the subject "Fundamentals of body language; motor games in early childhood education ', present in the 2nd year of the master's degree in early childhood education. With the intention of delivering a service to children with disabilities, the programme design specifically led to the planning and carrying out of practical motor games sessions by pre-service teachers, in which subject knowledge was to be applied. The service provided helped foster the development of children and motor learning, based on the specific and diverse particularities of the cases involved (Downs syndrome as well as physical impairments such as cerebral palsy). The programme was planned for one academic year. Certain characteristics from models of reference such as Richards, Wilson and Eubank (2012) and Vickerman (2007) were taken into account for the design. The participation of pre-service teachers was sequenced in monthly blocks at the rate of 6-8 participants in each. All the pre-service teachers worked with the same groups of children and constantly needed to be decision-makers, having the full responsibility to make changes according to the requirements of each moment. Each pre-service teacher undertook previous training of 10 theoretical classes and 2 seminars delivered by the teachers involved and the experts from the associations responsible for the children. In total each pre-service teacher dedicated 30 hours, 8 hours of direct contact with the children and the rest in preparation, reflection and evaluation. These phases were supervised by their professors.

\section{Instruments}

\section{Effective personality questionnaire for university students}

The effective personality questionnaire for university students (EPQ-US) developed by Gómez (2012) was used for the quantitative phase. This is a valid and trustworthy instrument. In terms of reliability and validity, Gómez (2012) obtained a reliability of 0.87 in the alpha consistency index (Cronbach's alpha) and acceptable results in the analysis of predictive validity and content validity. She carried out a first-order initial factor analysis and a second-order factorial analysis in order to reduce the initial factors to simplify the subsequent analyses, concluding that the items of the resulting dimensions were maximally related to each other and minimally to those of other sub-sets. Finally, she carried out a third Confirmatory Factor Analysis (CFA), using Structural Equation Models (SEM), which indicated that the data were reasonably adjusted to the EP theoretical model.

Some illustrative items of the four dimensions that make it up are for example, no.17-I study because I like to overcome the challenges presented to me by the subject material (Academic self-realisation), no.18-I am certain I will succeed in my relationships with others (Social self-realisation), no.7-There are many things about myself that I would change if I could '(Self-esteem), and no.4-When I have to make a decision, I plan carefully what I will do' (Problem solving self-efficacy). 


\section{Semi-structured interviews}

Semi-structured interviews took place in which open questions were first used that became more specific later so as to impede the researcher reference framework imposing itself on the points of view of the interviewees. Some questions included were: 'What was your experience on the programme like?', 'Would you still work with the same group in future projects or prefer to change?

\section{Learning journals}

At the end of the programme, the researchers asked participants to send their daily personal reflections. The students had to previously reflect and write on the following themes: noteworthy experiences, personal learning and academic learning.

\section{Data analysis procedures}

\section{Quantitative data analysis}

The Kolmogorov-Smirnov test found that the distribution of the sample was not normal, so the option of non-parametric testing was taken. To check whether there were significant differences $(p<.05)$ between the post-tests in both group measurements the Mann-Whitney U test was used. To compare the pre and post-test differences of the experimental group the Wilcoxon test was performed. Finally, the results of each of the four dimensions of the questionnaire were compared.

\section{Qualitative data analysis and trustworthiness}

The data collected from interviews and learning journals was analyzed through a multiphase approach. In the initial open-coding phase, information relating to the description of experiences, thoughts and feelings experienced by the pre-service teachers was identified. This phase implied that the researchers should analyze the emerging units of significance and that these should be contrasted by a constant comparison method (Patton, 2002). In the second stage of axial coding, the analysis focused on identifying information relating to EP construct nuclei. Researchers moved between inductive and deductive thinking (Flick, 2007), complementing the quantitative results of the study. These categories were established when they began to be theoretically saturated (idea saturation and not data) as common patterns were found and identified. After, there was a third moment of inter-verification of units of significance. On the one hand, the investigative team (initially composed of two members), carried out a process of 'member checking' based on submitting the results for interviewee verification. Finally, a new investigator and reviewer of the critical analysis was invited to participate to confirm the results. 


\section{Findings}

\section{Quantitative results}

To contrast the results obtained in the EPQ-US post-test between the experimental group and the control group the Mann-Whitney U test was applied. Globally, statistically significant differences in favour of the experimental group were found, obtaining a result of $Z=-2.27 ; p=0.23,(<.05)$. Figure 1 shows the results obtained by each group according to the dimensions of the questionnaire.

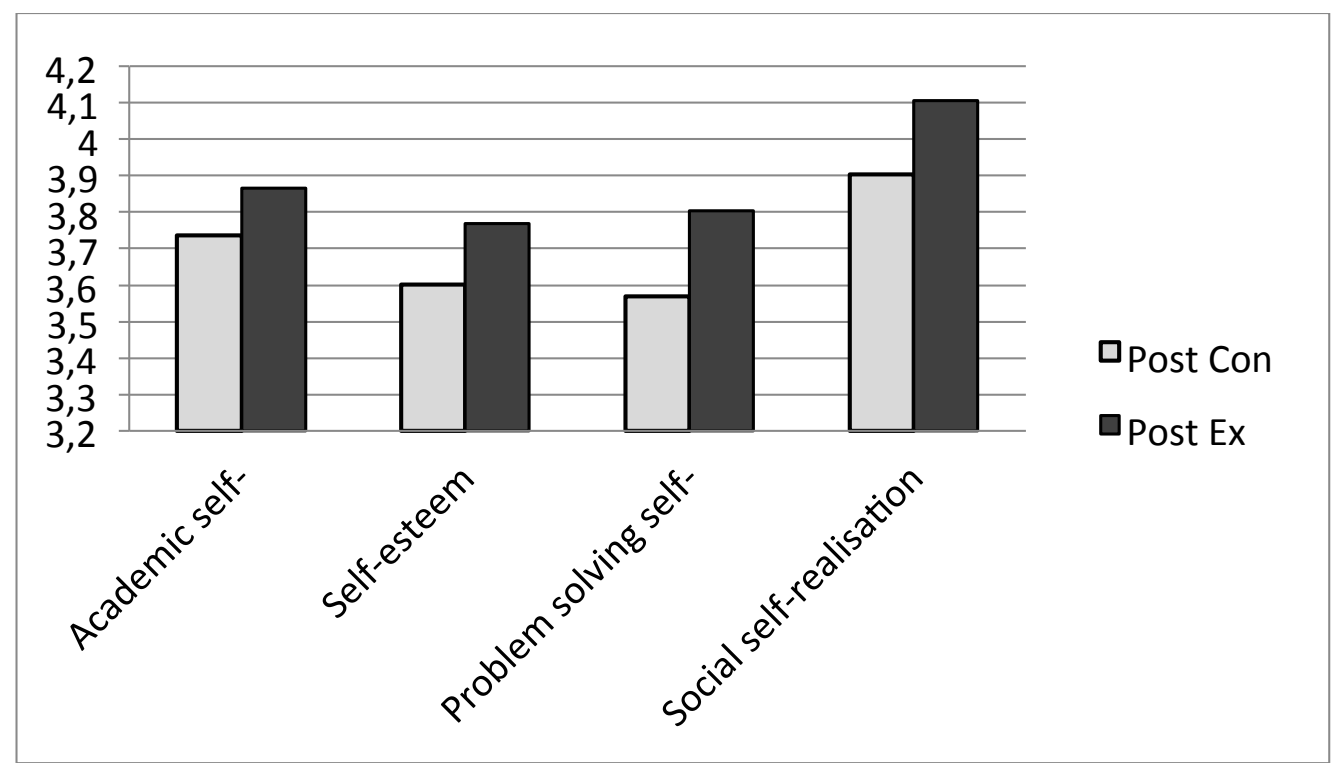

Figure 1. EPQ-US experimental and control post-test results by dimension

The difference between the results obtained by both groups in the pre- and posttest measurements was also compared with the Wilcoxon test. While the control group revealed no significant differences between the two measurements $(Z=-0.78 ; p$ $=.434,>.05)$, some statistically significant differences between pre- and post-test measurements of the experimental group were found, earning a score of $Z=-3.81 ; p=.00$, $<.05$ manifesting the EP improvement of the SL programme participants. In order to gain more detailed knowledge of these improvements, the dimensions between the pre- and post-test in both groups were compared. Statistically significant differences in the nuclei were obtained with a result of $Z=-2.38 ; p=.017,<.05$ for self-esteem; and in the social self-realisation nucleus a score of $\mathrm{Z}=-2.54 ; p=.011,<.05$. Figure 2 shows these results. 


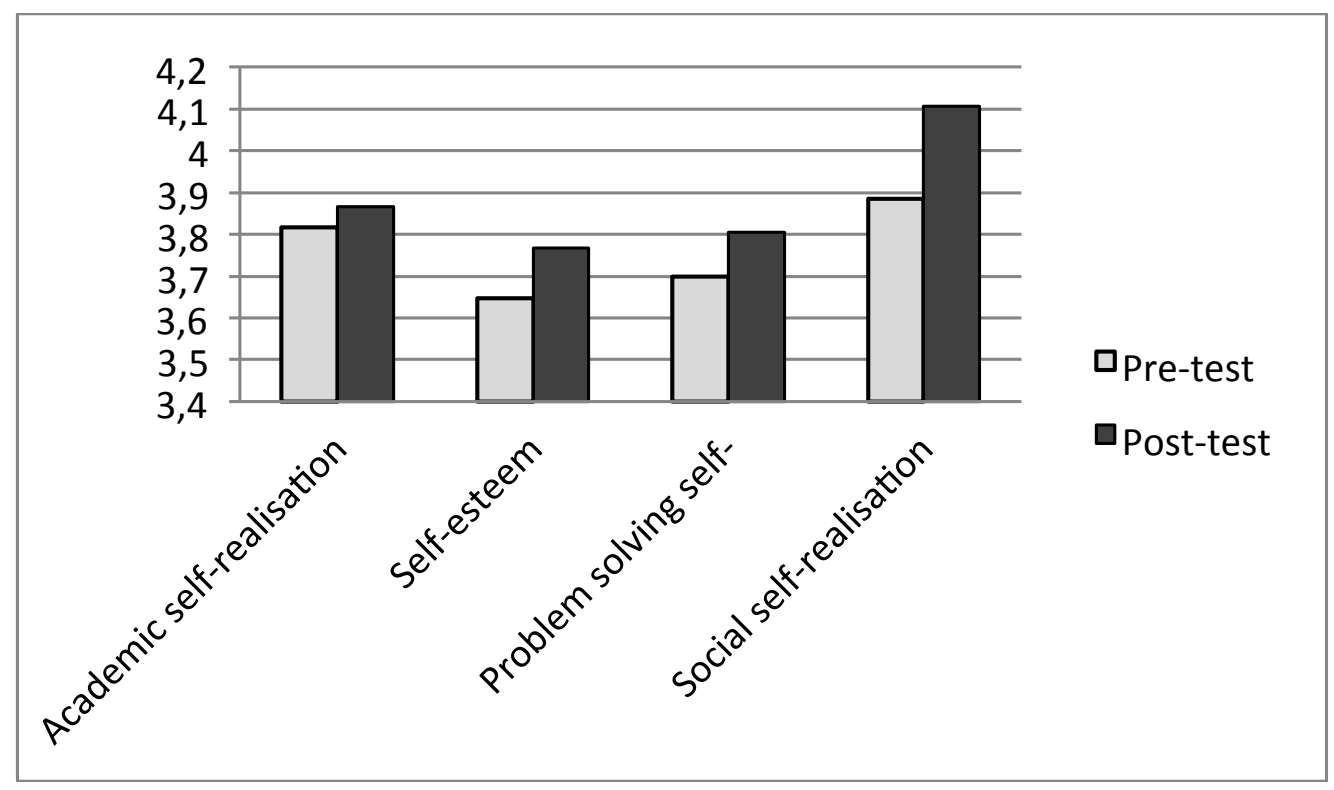

Figure 2. EPQ-US pre and post-test experimental group results by dimension

\section{Qualitative results}

The qualitative analysis reveals improvements in the next categories: 'Relationship between theory and practice', 'Problem-solving self-efficacy', 'Self-esteem and Social self-realisation'.

\section{Relationship between theory and practice}

The qualitative analysis of interviews and journals revealed that programme participants highlighted many common themes. Apart from EP relating to contents to be focussed on later, the allusion to the ideal nature of SL to practically broaden what is learned in theory is a recurring element.

'It's good to have subjects like this to relate a little theory with practice, because they change so much (...) I think it changes a lot from theory to practice. It>s totally different.) (Journal 38).

In this experience, SL breaks the fragility of the relationship between theory that exists in higher education, where in many cases academic learning focuses on theoretical knowledge and acquisition, SL contributes to greater pedagogical coherence in this area of pre-service teacher training.

<The experience has helped me to make practical decisions such as when to include free or directed games at certain times of the session (...) This kind of thing we have seen in theory and here we could implement this and understand it better.) (Interview 3). 
A reciprocal relationship is seen in which the knowledge and action parts feedback on each other and are at the same level or degree of importance.

¿ learned to have to prepare alternative activities in case anything might happen and also to be doing an activity and suddenly have to change by completely improvising (...). So I think that experience solves this. For all the theory you know, until you $>$ re there and you live it, you cannot really learn it.> (Journal 23).

Arguably SL responds to an experiential teaching model in which students do not act as a mere receiver, but actively learn.

«We practice and learn the true reality of our profession most significantly every Saturday, when we meet those kids.> (Journal 18).

This experiential learning model facilitates the development of EP related to increased self-esteem and concept of self, social skills development and the ability to work in teams, employing strategies to solve specific problems, etc. (Álvarez, 2012).

\section{Problem solving self-efficacy}

The increase of the relationship between theory and practice may have a direct effect on pre-service teachers developing self-efficacy. The SL programme participants were engaged in a constant process of decision making and coping with problems. This scenario led them to improve their effectiveness in resolving changing situations that arose in the programme.

'Drawing from the experience of the first session, we decided to give well prepared sessions, but always being willing to adapt games and activities to current child needs and demands.' (Interview 11).

In fact, some participants directly confessed that after the SL experience they appeared better able to apply the knowledge acquired during their training.

'I would now be more able to push these sessions through, because even if you have a programmed scheme of work, you can take that out if it does not fit with the children or because they are bored or they find things too easy or difficult, etc. I have learned to react to these situations to try to adjust things more to the needs and interests of the moment.' (Interview 12).

This learning fits perfectly with the definition of problem solving self-efficacy, as it led them to carefully plan their decisions, adapting time demands and gathering as much information as possible.

\section{Self-esteem}

There were also numerous descriptions of the feelings and certain moments in which the infant school pre-service teachers explained their satisfaction with themselves and the work they considered had been well done. These aspects are directly connected to self-esteem and the concept of self.

'We get the satisfaction of having been able to work with these children, learning from their difficulties and having met the objectives. The most rewarding thing was working with children who have given us their smile and affection without expecting anything in return.' (Journal 43). 
Many of these affirmations appeared as a response to the conduct or commentaries of the children or even the families they worked with.

'When a mother told me that the child went to the calendar each week to record the session on Saturday, I was really glad. That means that the child likes to come to the sessions and personally I'm glad they think so. That fills me with pride and it means I am doing something well.' (Interview 2).

Undoubtedly, the satisfaction caused by the feeling of a job well done and the fulfillment of the objectives impacted on the self-esteem of the pre-service teachers. In addition, the great potential of this direct delivery was reflected on in its application.

'The feelings you experience after contact with these children is sensational. To me they are a great example of struggling to overcome difficulty because sometimes they told me they wanted a tougher game or to throw the ball farther and they wanted to challenge themselves.' (Journal 17).

Some pre-service teachers even highlight how the involvement and commitment of the SL experience had transcended the academic demands, raising this commitment to the context of social reality.

'We've set aside the idea that is 'a class project' to think more about the personal interaction with the children.' (Journal 34).

\section{Social self-realisation}

Regarding the pre-service teacher improvement of social self-realisation, the strong existing social interaction with different programme agents should be noted.

'To prepare the motor games sessions we had six or seven meetings. Just commenting and discussing things with peers allows you to see things from another point of view. That has allowed me to approach work differently and appreciate the work of organizing things that cannot be seen by with a simple look.' (Interview 1)

Thanks to this interaction experienced by the participants, a clear perception of improvement in skills such as communication, assertiveness and empathy is detected.

'I think with this experience I have learned to work as part of a group. If I now have to re-do group work and had a problem with someone, I would say things clearly from the start. I think it's better to put all the cards on the table from the beginning.' (Interview 1).

The clear perception of the personal ability to establish and maintain relationships with others helped improve the successful prospects of future social relationships.

'Highlighting the help and advice we have received during the period of SL from families and teachers with whom we have worked; this interaction has helped us to learn to understand and connect with different people, extending our track record in this regard.' (Journal 47).

It may be said that the SL experience allowed the pre-service teachers to improve the confidence and appreciation of their resourcefulness in building new social relationships.

In short, the work of qualitative analysis especially reveals the effect on problemsolving self-efficacy, self esteem and social self-realisation of SL. However, the same cannot be said of academic self-realisation, despite pre-service teacher-cited improvements in the theory-practice relationship. 


\section{Discussion}

The results of the quantitative and qualitative analysis models were complimentary in meeting the research aims. According to the main hypothesis and study research question, participation in the SL programme improved EP for pre-service teachers. Overall, these results are consistent with that those of Bernadowsky, et al. (2013) who note how preservice teachers participating in SL become more reflective and able to solve interaction issues concerning both classmates and other social agents. In this line, Conrad and Hedin (1989) refer to the positive contribution the influence of SL makes on pre-service teachers in terms of learning content as well as professional growth. Also, Buchanan et al. (2002) refer to the benefit of SL participation on the very concept of what being a teacher means, noting that training involving some kind of social service increases student sensitivity.

There are statistically significant differences between the pre- and post-test measurements in the partial analysis of the four construct dimensions of the experimental group. This indicates that programme participation had a positive outcome. Furthermore, the qualitative analysis provided evidence that the authentic interaction in SL is an appropriate scenario for the development of social self- related characteristics like empathy, assertiveness and communication skills. Consistent with these results, there are several studies that indicate the effects of SL promote positive changes in the social skills of students. Maynes et al. (2013) suggest improvements in pro-social attitudes of pre-service teachers after SL. Other studies report bettered ability to empathise, stating that the SL increases empathy towards disadvantaged social groups or sectors (Perry \& Katula, 2001). Regarding the development of pro-social skills and social interaction, Ammon Furco, Chi and Middaugh (2002) and Yates and Youniss (1997) show improved civic attitudes and social interaction. Moreover, Astin and Sax (1998) also agree with this view because of the longitudinal studies from different levels of education. Billig (2002) and Conrad and Hedin (1989) each reaffirm this in literature reviews based on the effect in different contexts and educational levels of SL.

Statistically significant differences between the pre- and post-test measurements of the experimental group were also found in the self-esteem dimension. This reveals that participation in the programme resulted beneficial. For its part, the qualitative analysis shows the positive impact of SL on the perception of pre-service teachers as valuable to other people. Thus, the results of this dimension indicate that learning by overcoming conflict and problems in real contexts leads to a greater understanding and appreciation by the pre-service teachers of themselves, as well as increased confidence. The results are fully consistent with investigations that report SL provokes the effect of improving the student concept of self and self-esteem (Conrad \& Hedin, 1989; McMahon, 1998; Yates \& Youniss, 1997).

In the problem solving self-efficacy dimension, although the results of quantitative analysis did not show statistically significant improvements, indications improve with the observed qualitative analysis results, which are derived from perceptions of improvement in features such as coping with changing situations effectively. In fact, some participants admitted the SL experience made them feel better able to apply the knowledge that was acquired. These results are consistent with several studies that point to the influence of SL on improving features such as empowerment and student self-efficacy. For example, 
Bernadowsky et al. (2013) refer to improvements in SL pre-service teachers regarding the perception of their skills as future teachers. Billig (2000), refers to improved student empowerment, self-efficacy and resilience. McMahon (1998) points out SL benefits on the perception of the decision-making capacity of student teachers. As far as the skills of planning decisions and situational analysis there is research that regards the results obtained here, among which can be highlighted that by Lewellyn and Kiser (2014), referring to intellectual growth, critical thinking and problem analysis, and that of Wendler (2012), directly referring to increased decision-making capacity.

Finally, academic self-realisation is the dimension in which this study reflected the least clear impact on applied SL. Neither with the qualitative nor quantitative results can it be said that the influence from the SL programme on the development of the motivation and capacities for academic performance is significant. As is the case in our study, Billig, Root and Jesse (2005) collected better scores after SL programme participation, although their differences attributed inconclusive results. Neither are the results from our research as strongly conclusive as those presented by Gallini and Moely (2003), who attributed the ability to motivate university students in relation to the expectations and responsibilities of academic performance, nor are our results as strong as those of Moser and Rogers (2005), who report an increase in the willingness of students to learn, increasing their capacity for effort and expectations of success.

However, a nucleus of content that was relevant emerged from the analysis phase that was indirectly related to the academic realisation that the authors term the theory-practice relationship. The pre-service teachers gained from SL the capacity to expand in practice what had been learned from in theory, reinforcing the reciprocal relationship between theoretical knowledge and practical experience. Similar results were reported by Wilkinson et al. (2013) in a study on student teacher experiences in a SL programme. Moreover, Tindall et al. (2015) and Vickerman and Coates (2009) make reference to the benefits of the practical experience in increasing the confidence, understanding and comfort of pre-service teachers.

This feedback could be due to the participation of personality related features like the effective increase of self-esteem, the development of social skills and the ability to work as a team and deal with problems (Álvarez, 2012). E Thus, this core of content revealed a reality that remained unnoticed in the quantitative analysis. The logical thing would have been that the pre-service teachers related the ability to supplement theory and practice with an improvement in their academic self-realisation. However, according to the results of the questionnaire the pre-service teachers did not directly correlate these attributions to their best academic efforts, perhaps being due to the reflection inherent in the process of writing the journals and to the verbalization of the interviews having increased their learning awareness.

\section{Conclusions}

The development of skills related to EP improvement has become one of the most important missions for higher education in the twenty-first century. In that regard, SL may seem to represent an optimal educational methodology that achieves these goals, while at the same time offering valuable local community services. The present 
study confirms this hypothesis through the following conclusions. The group that participated in the SL programme fared better in the EPQ-US than the group that did not. Similarly, the EP levels obtained by the SL participants were significantly better after the completion of the programme. The quantitative analysis of the data indicated that these advances occurred in a meaningful way in the self-esteem and socialrealisation dimensions. These results were consistent with the perception expressed by the pre-service teachers themselves in interviews and daily monitoring. From the qualitative part of the analysis, the improvement of the problem-solving capacity dimension was strongly apparent, although this improvement was not as evident in the quantitative analysis. These conclusions reinforce the case to continue using SL for PSTs and investigating its effects in the ambit of physical education and community education in the future.

\section{References}

Álvarez, C. (2012). ¿Qué sabemos de la relación entre la teoría y la práctica en la educación? Revista Iberoamericana de Educación, 60(2), 1-11.

Álvarez, J. L., Martínez, M. J., González, H., Buenestado, \& Fernández, M. (2017). El aprendizaje-servicio en la formación del profesorado de las universidades españolas, Revista española de pedagogía, 75(267), 199-217.

Ammon, M.S., Furco, A., Chi, B., \& Middaugh, E. (2002) Service-Learning in California: A Profile of the CalServe Service-Learning Partnerships (1997-2000). Berkeley: University of California, Service-Learning Research and Development Center.

Astin, A.W., \& Sax, L.J. (1998). How undergraduates are affected by service participation. Journal of College Student Development, 39(3), 251-263.

Bandura, A. (1975). The Ethics And Social Purposes Of Behaviour Modification. In: F., Cyril \& W. Terence. Annual Review Of Behavior Therapy Theory And Practice (pp. 13-20). New York: Brunner/Mazel.

Bar-On, R. (2006). The Bar-On Model Of Emotional-Social Intelligence (Esi). Psicothema, 18, 13-25. Recuperado de http://www.psicothema.com/psicothema.asp?id=3271

Bernadowsky C, Perry, R., \& Del Greco, R. (2013). Improving Preservice Teachers' Self-Efficacy through Service Learning: Lessons Learned. International Journal of Instruction, 6(2), 67-86. Recuperado de https://eric.ed.gov/?id=ED544043

Billig, S.H. (2000). Research on K-12 school-based service-learning: the evidence builds. Phi Delta Kappan, 81, 658-664. Recuperado de https://eric.ed.gov/?id=EJ606453

Billig, S. (2002). Support For K-12 Service Learning Practice: A Brief Review Of The Research. Educational Horizons, 80, 184-189. Recuperado de https://www.jstor.org/ stable/42927126?seq=1\#page_scan_tab_contents

Billig, S., Root, S., \& Jesse, D. (2005). The Impact Of Participation In Service Learning On High School Students' Civic Engagement. EEUU: Circle, Center for Information and Research on Civic Engagement and Learning.

Bringle, R.G., \& Hatcher, J.A. (1996). Implementing service-learning in higher education. Journal of Higher education, 67, 221-239

Buchanan, A.M., Baldwin, S.C., \& Rudisill, M.E. (2002). Service Learning as Scholarship in Teacher Education. Educational Researcher, 31(5), 28-34. 
Carson, R. L., \& Raguse, A. L. (2014). Systematic Review Of Service-Learning In Youth Physical Activity Settings. Quest, 66(1), 57-95. doi: https://doi.org/10.1080/0033629 7.2013.814578

Cervantes, C. M. \& Meaney, K. (2013). Examining Service-Learning Literature In Physical Education Teacher Education. Quest, 65(3), 332-353. doi: https://doi.org/10.1080 /00336297.2013.773533

Chambers, D., \& Lavery, S. (2012). Service-Learning: A Valuable Component Of PreService Teacher Education. Australian Journal Of Teacher Education, 37(4), 128-137. doi: https://doi.org/10.14221/ajte.2012v37n4.2

Crichton, H., \& Templeton, B. (2013). Collaboration or confrontation? An investigation into the role of prior experiences in the completion of collaborative group tasks by student teachers. European Journal of Teacher Education, 36(1), 84-96. doi: https://doi. org/10.1080/02619768.2012.678487

Conrad, D., \& Hedin, D. (1989). High School Community Service: A Review Of Research And Programs. Madison, Wi: National Center On Effective Secondary Schools.

Crawford, S. (2011). An examination of current provision in primary and special schools in Ireland. European Physical European Review, 17(1), 91-109.

Deeley, S., J. (2015). Critical perspectives on service-learning in higher education. New York, NY: Palgrave MacMillan.

Flick, U. (2007). Introducción a la Investigación cualitativa. Madrid, España: Morata.

Gardner, H. (1983). Frames of Mind. The Theory of Multiple Intelligences. Nueva York: Basic Books.

Gallini, S., \& Moely, B. (2003). Service-learning and engagement: Academic challenge and retention. Michigan Journal of Community Service Learning, 10(1), 5-14.

Gil-Gómez, J., Chiva-Bartoll, O., Martí-Puig, J. (2015). The impact of service learning on the training of pre-service teachers: Analysis from a physical education subject, European Physical Education Review, 21, 467-484.

Gil-Gómez, J. Moliner-García, O., Chiva-Bartoll, O., García-López, R. (2016) Una experiencia de aprendizaje-servicio en futuros docentes: desarrollo de la competencia social y ciudadana, Revista Complutense de Educación, 1, 53-73.

Gómez, R. (2012). Evaluación de la personalidad eficaz en población universitaria (Phd Thesis). Universidad de Huelva, Huelva, España

He, Y., \& Prater, K. (2014). Writing together, learning together: teacher development through community learning service. Teachers and Teaching, 20(1), 32-44. doi: https:// doi.org/10.1080/13540602.2013.848512

Heath, D.H. (1965). Explorations of maturity. N.Y. Apleton: Century Crofts.

Hébert, A., \& Hauf, P. (2015). Student learning through service-learning: Effects on academic development, civic responsibility, interpersonal skills and practical skills. Active Learning in Higher Education, 16(1), 37-49. doi: https://doi.org/10.1177/1469787415573357

Kristén, L., Patrik, G. \& Fridlund, B. (2002). Conceptions of children and adolescents sson with physical disabilities about their participation in a sports programme. European Physical Education Review, 8(2),139-156.

Lewellyn, A., \& Kiser, P.M. (2014). Conceptualizing critically as a guiding principle for high quality academic service learning. International journal of teaching and learning in higher education, 26(1), 147-156. Recuperado de https://eric.ed.gov/?id=EJ1043032 
Martín del Buey, F., Fernández, A., Martín, E., Dapelo, B., Marcone, R., \& Granados, P. (2008). Cuestionario de personalidad eficaz para la formación profesional. Psicothema, 20(2), 224-228.

Martín Del Buey, F., Granados, P., Martín, M. E., Juárez, A., García, A. \& Álvarez, M. (2000). Desarrollo De La Personalidad Eficaz En Contextos Educativos. Marco Conceptual. Oviedo: Fmb.

Maynes, N., Hatt, B., \& Wideman, R. (2013). Service Learning as a Practicum Experience in a Pre-Service Education Program. Canadian Journal of Higher Education, 43(1), 80-99.

Mayor, D., \& Rodríguez, D. (2016). Aprendizaje-servicio y práctica docente: una relación para el cambio educativo. Revista de Investigación Educativa, 34(2), 535-552. doi: http:// dx.doi.org/10.6018/rie.34.2.231401

McMahon, R. (1998). Service-learning: perceptions of preservice teachers. 27th Annual Meeting of the Mid-South Educational Research Association, New Orleans, LA.

Megan, S., \& MacPhail, A. (2006). Irish physical educators' attitude toward teaching students with special educational needs. European Physical Education Review, 12(1), 75-97.

Melchior, A., \& Orr, L. (1995). Final report: National evaluation of Serve America. Washington, DC: Corporation for National and Community Service.9

Monroy, F., \& González-Geraldo, J.L. (2017). Teaching conceptions and approaches: do qualitative results support survey data? Revista de Investigación Educativa, 35(1), 167-180. doi: http://dx.doi.org/10.6018/rie.35.1.237621

Morley, D., Balley, R., Tan, J., \& Cooke, B. (2005). Inclusive Physical Education: teachers' views of including pupils with Special Educational Needs and/or disabilities in Physical Education, European Physical Education Review, 1(1), 84-107.

Moser, J. M., \& Rogers, G. E. (2005). The Power Of Linking Service To Learning. Tech Directions, 64(7), 18-21.

Patton, M. Q. (2002). Qualitative Research And Evaluation Methods (3rd Ed.). Thousand Oaks, Ca: Sage.

Perry, J. L., \& Katula, M. C. (2001). Does Service Affect Citizenship? Administration And Society, 33 (3), 330- 365.

Richards, A. K. R., Wilson, W. J., \& Eubank, L. (2012). Planning A Service-Learning Program To Benefit Children With Disabilities. Journal Of Physical Education, Recreation And Dance, 83(7), 32-38. doi: https://doi.org/10.1080/07303084.2012.10598810

Richards, K.A.R., Eberline, A.D., Padaruth, S., \&Templin, T. J. (2015). Experiential learning through a physical activity program for children with disabilities. Journal of Teaching in Physical Education, 34, 165-188.

Rodríguez, M. (2014). El Aprendizaje-Servicio como estrategia metodológica en la Universidad. Revista Complutense de Educación, 25(1), 95-113.

Salovey, P., \& Mayer, J. D. (1990). Emotional Intelligence. Imagination, Cognition, And Personality, 9, 185-211.

Tindall, D., MacDonald, W., Carroll, E., \& Moody, B. (2015). Pre-Service Teachers' Attitudes Towards Children With Disabilities: An Irish Perspective. European Physical Education Review, 21(2), 206-221. doi: https://doi.org/10.1177/1356336X14556861

Vaillant, G. E., \& Milofsky, E. (1980). Natural History Of Male Psychological Health. American Journal Of Psychiatry, 33, 1348-1359. 
Vickerman, P. (2007). Training physical education teachers to include children with special educational needs: Perspectives from physical education initial teacher training providers. European Physical Education Review, 13(3), 385-402.

Vickerman, P., \& Coates, J.K. (2009). Trainee and recently qualified physical education teachers' perspectives on including children with special educational needs. Physical Education \& Sport Pedagogy, 14, 137-53. doi: https://doi.org/10.1080/17408980802400502

Waters, S., \& Anderson-Lain, K. (2014). Assessing The Student, Faculty, And Community Partner In Academic Service-Learning. Journal Of Higher Education Outreach And Engagement, 18(1), 89-122.

Watson, D. L., Crandall, J., Hueglin S., \& Eisenman, P. (2002). Incorporating Service Learning Into Physical Education Teacher Education Programs. Journal Of Physical Education, Recreation And Dance, 73(5), 50-54.

Wendler, R. (2012). Human Subjects Protection: A Source For Ethical Service-Learning Practice. Michigan Journal Of Communty Service Learning, 18(2), 29-39.

Wilkinson, S., Harvey, W. J., Bloom, G. A., Joober, R., \& Grizenko, N. (2013). Student Teacher Experiences In A Service-Learning Project For Children With AttentionDeficit Hyperactivity Disorder. Physical Education And Sport Pedagogy, 18(5), 475-491. doi: https://doi.org/10.1080/17408989.2012.690385

Yates, M., \& Youniss, J. (1997). Communitv service and social responsibilitv in youth. Chicago: University of Chicago Press.

Fecha de recepción: 1 de septiembre de 2017.

Fecha de revisión: 18 de septiembre de 2017.

Fecha de aceptación: 27 de noviembre de 2017. 
